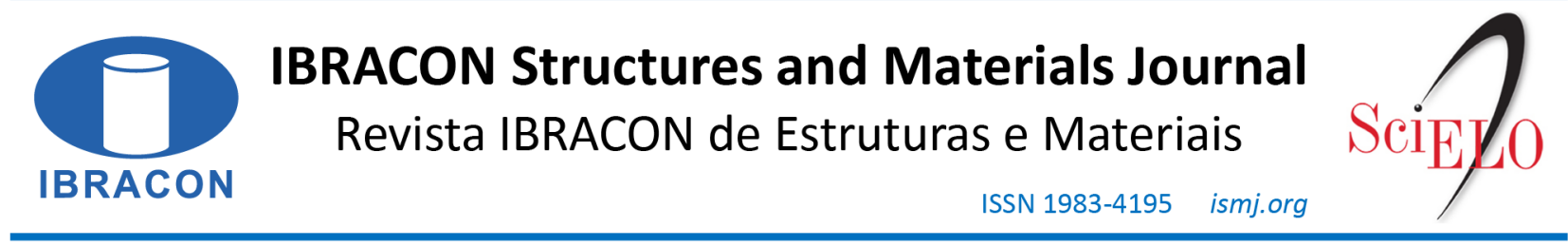

ORIGINAL ARTICLE

\title{
Theoretical analysis of the behavior of steel frame infilled with masonry walls by the diagonal strut method
}

\section{Análise teórica do comportamento de pórtico de aço preenchido com alvenaria participante pelo método da barra diagonal equivalente}

\author{
Alba Bruna Cintra De Grandi ${ }^{\mathrm{a}}$ (D) \\ Roberto Márcio da Silva ${ }^{a}$ \\ Rita de Cássia Silva Sant'Ana Alvarenga ${ }^{\mathrm{b}}$ \\ José Carlos Lopes Ribeiro ${ }^{\mathrm{b}}$ \\ Guilherme Aris Parsekian ${ }^{\mathrm{c}}$ \\ Wallison Angelim Medeiros ${ }^{\mathrm{c}}$
}

\begin{abstract}
${ }^{a}$ Universidade Federal de Minas Gerais - UFMG, Departamento de Engenharia de Estruturas, Belo Horizonte, MG, Brasil

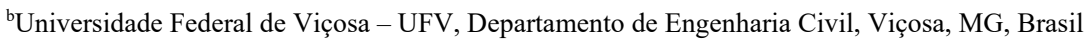

${ }^{c}$ Universidade Federal de São Carlos - UFSCar, Departamento de Engenharia Civil, São Carlos, SP, Brasil
\end{abstract}

Received 10 October 2019

Accepted 22 September 2020

\begin{abstract}
In the last decades, several studies have been developed regarding structures composed by frames infilled with masonry walls, proving the increase of lateral stiffness by the infill. In this work, an analysis was carried out, based on design codes which adopt the equivalent diagonal strut method, to compare theoretical results with experimental ones of tests performed on steel frames infilled with concrete block masonry. Two of the three assessed codes specify lateral stiffness smaller than that measured from experimental testing, as safety measures for design. Regarding the masonry ultimate loads, the two specifications analyzed yielded similar values of critical force, although they pointed out different failure modes. The equivalent diagonal strut method has been proved to be a simple and useful tool for considering masonry walls and it should be used in case of reduced horizontal loads, prior to initial cracks of the infill wall.
\end{abstract}

Keywords: structural masonry, infilled frame, equivalent diagonal strut method, theoretical evaluation.

Resumo: Nas últimas décadas, inúmeros estudos têm sido desenvolvidos a respeito de estruturas de pórticos preenchidos com alvenaria participante, comprovando o aumento de rigidez lateral proporcionado por esta. Neste trabalho, análise foi realizada, baseada em prescrições normativas que adotam o método da barra diagonal equivalente, com o objetivo de comparação aos resultados experimentais de ensaios de pórtico de aço preenchido com alvenaria de blocos de concreto. Duas das três normas técnicas estudadas sugeriram valores de rigidez lateral inferiores aos resultados experimentais, como condição de segurança ao dimensionamento. Sobre as forças de ruptura da alvenaria, os dois procedimentos analisados apresentaram valores próximos de força crítica, embora tenham apontado modos críticos de colapso distintos. O método da barra diagonal equivalente se mostrou uma ferramenta útil e simples para a consideração da alvenaria participante, devendo ser empregado em caso de ações horizontais reduzidas, prévias ao estágio inicial de fissuração do painel.

Palavras-chave: alvenaria estrutural, pórtico preenchido, método da barra diagonal equivalente, avaliação teórica.

How to cite: A. B. C. De Grandi, R. M. Silva, R. C. S. S. Alvarenga, J. C. L. Ribeiro, G. A. Parsekian, and W. A. Medeiros, “Theoretical analysis of the behavior of steel frame infilled with masonry walls by the diagonal strut method", Rev. IBRACON Estrut. Mater., vol. 14, no. 5, e14508, 2021, https://doi.org/10.1590/S1983-41952021000500008

Corresponding author: Alba Bruna Cintra De Grandi. E-mail: alba_cdg@hotmail.com

Financial support: Coordenação de Aperfeiçoamento de Pessoal de Nível Superior - Brasil (CAPES) - Código de Financiamento 001.

Conflict of interest: Nothing to declare. 


\section{INTRODUCTION}

Over the past few decades, several researchers have confirmed that masonry infills have a significant influence on the behavior of framed structures. The infill increases frame stiffness and, consequently, helps limit the displacements of the structure when subject to lateral forces [1], [2]. However, in most cases, infill walls are treated only as partition member and their influence on the behavior of the structure is not considered [2], [3]. Nevertheless, the practice of disregarding the structural interaction between the masonry wall and the surrounding frame can lead to less economical projects and does not necessarily result in a safer design. Unexpected and undesirable behavior of the structure may occur when disregarding the infill, especially regarding its dynamic behavior, which can have its natural vibration period reduced and the ductile failure mode changed to a brittle failure mode [4]-[6].

Several models have been proposed for the design of masonry infill panels [3], the equivalent diagonal strut method being the most widespread. In this model, the infill panel is replaced by a diagonal strut, with defined geometric and mechanical properties (Figure 1), which is activated under compression to resist the loading.
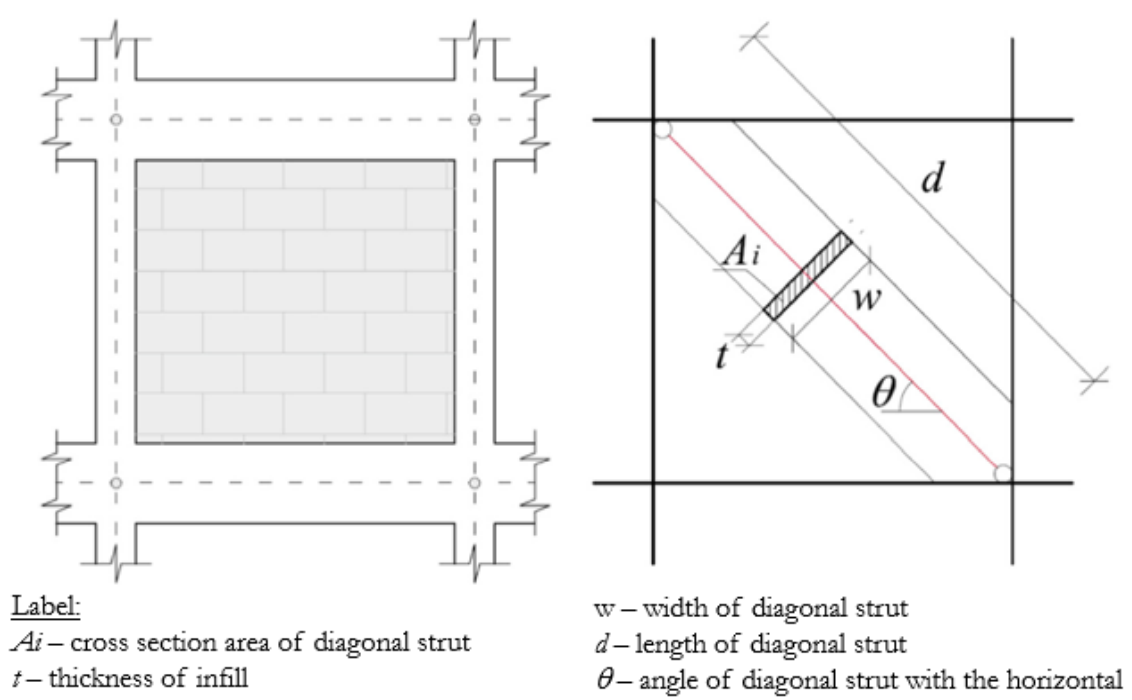

Figure 1. Definition of the diagonal strut and its geometric characteristics. Source: Adapted from Asteris et al. [7]

Based on this model, some design codes specifications were developed or reformulated in order to quantify the stiffness and strength provided by the masonry walls, so that their consideration as infill panels in a structural design is possible. Analytical models based on the equivalent diagonal strut method comprise the most effective way to include the contribution of stiffness and strength of the infill panels in framed structures, overcoming the enormous computational effort required by refined models using the Finite Element Method [7], [8].

However, despite numerous research and evidence regarding the efficiency of infilled frames, the most widespread analytical methods and calculation procedures have not achieved practical application in Brazil yet. Thus, designers still tend to disregard masonry as a bracing element, mainly due to the lack of a normative guideline comprising projects that consider the contribution of infill panels [9], [10].

In fact, due to the complexity and non-regularity of the infill's behavior, uncertainties still persist on this subject. Many factors such as material properties, type of loading, openings in walls and construction details lead to complex behavior of the system [6], [11]-[13].

Therefore, this work was carried out to contribute to a better understanding of the behavior of infilled framed structures, investigating the stiffness gain provided by the presence of masonry wall. The main objective was to evaluate methods proposed by standard codes that consider masonry walls as bracing elements, comparing the theoretical results with experimental results obtained by De Grandi [14]. The analysis assessed the lateral displacements of the structure considering the determination of the effective width of equivalent diagonal strut, as well as ultimate lateral forces of the infilled panel. It is noteworthy, however, that this work was exclusively restricted to the theoretical analysis of analytical methods that provide the consideration of masonry infill. Reader should refer to De Grandi [14] for details on the experimental tests. 


\section{THE EQUIVALENT DIAGONAL STRUT METHOD}

Polyakov [15] was one of the pioneers in presenting approximate methods that allow the consideration of masonry on infilled frame structures. He introduced the concept of the equivalent diagonal strut, which was later developed by Holmes [16].

It was observed [15] that the application of a lateral load on the structure causes separation between infill and frame in a significant length on each side, leaving only a limited contact area at the compressed corners. In contrast, Holmes [16] suggested that the geometry of the diagonal strut is a function of the dimensions and physical properties of the infill wall. He indicates that the diagonal strut has the same thickness and modulus of elasticity as the masonry infill and its width can be taken as one third of its length. In addition, it was concluded that, at failure, the lateral displacement of an infilled frame is significantly lower than the displacement of the bare frame.

Stafford-Smith and Carter [17] were the first to propose an analytical equation to estimate the width of the equivalent diagonal strut. It was indicated that the diagonal stiffness of infill panel is not only a function of its dimensions and physical properties, but also depends on the contact length between frame and infill (Figure 2).

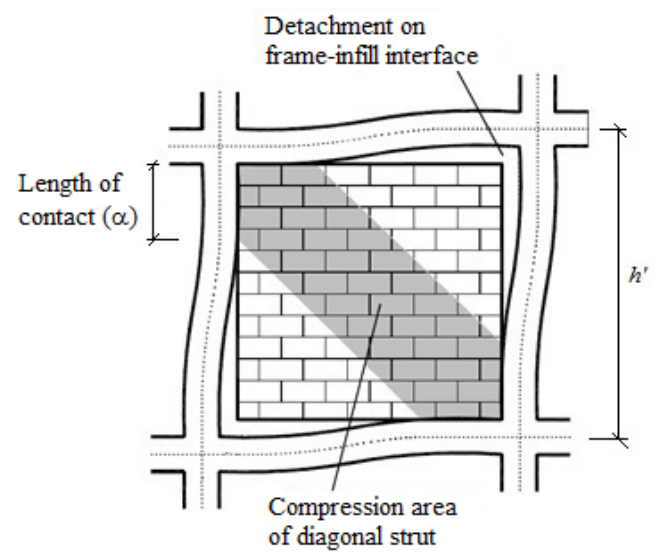

Figure 2. Length of contact between frame and infill. Source: Adapted from Asteris et al. [5]

This length of contact $(\alpha)$ is governed by the relative stiffness between panel and frame and can be estimated by Equation 1:

$\frac{\alpha}{h^{\prime}}=\frac{\pi}{2 \lambda h^{\prime}}$

where $\lambda h^{\prime}$ is a dimensionless parameter which expresses the relative stiffness between the frame and the infill panel, and $h^{\prime}$ is the height of the column between the beam axes. The parameter $\lambda$ can be determined by Equation 2 :

$$
\lambda=\sqrt[4]{\frac{E_{m} t \sin (2 \theta)}{4 E_{f} I_{c} h}}
$$

where $E_{m}, t$ and $h$ are the elastic modulus, the thickness, and the height of the infill panel, respectively; $E_{f}$ and $I_{c}$ are the modulus of elasticity and the moment of inertia of the column, and $\theta$ is the angle between the diagonal and horizontal axis.

From experimental investigations, the authors were able to affirm that, in case of multi-story structures, the column stiffness has an important influence on stiffness and on the final load capacity of the system. On the other hand, variations in the beam stiffness showed little effect on the behavior of the structure. The small influence of the beam member on the stiffness of the structure may be associated with the fact that, regardless of beam stiffness, the length of contact between beam and panel is approximately half of its span. 
Knowing the contact length between panel and frame, and carrying out a series of stress analysis, Stafford-Smith and Carter [17] concluded that the effective width of the diagonal strut is influenced by the following factors:

- relative stiffness between frame and panel;

- length-height ratio of the panel;

- stress-strain ratio of the infill material;

- intensity of the internal force acting on the diagonal.

Thus, Equation 3 was determined to calculate the width of the diagonal strut:

$$
w=\sqrt{\alpha^{2}+\left(\frac{l}{2}\right)^{2}}
$$

where $l$ is the span of upper beam of the frame.

Mainstone [18] adopted the equivalent strut model for steel frames and conducted a series of reduced-scale tests, with infill panels of microconcrete and ceramic block. He proposed equations to calculate the width of the diagonal strut for the two types of infill material, using the parameter $\lambda h$ ' by Stafford-Smith and Carter [17] Equation 4 refers to ceramic block infills, while Equation 5 refers to microconcrete ones.

$\frac{w}{L_{d}}=0.175\left(\lambda h^{\prime}\right)^{-0.4}$

$\frac{w}{L_{d}}=0.115\left(\lambda h^{\prime}\right)^{-0.4}$

where $w$ is the width of diagonal strut and $L_{d}$ is its length.

Wood [19], observing tests previously carried out by other researchers, in addition to categorizing four different failure modes for infilled frames, introduced a reduction factor of masonry compression strength $\left(f_{m}^{\prime}\right)$ in the model to achieve a reasonable approach to experimental results.

Liauw and Kwan [20] proposed a plastic theory observing three main modes of failure of the system, including the panel corners crushing and compressing of the diagonal. Using some of the previously defined parameters, Liauw and Kwan [20] presented Equation 6 for calculating the width of diagonal strut.

$$
w=\frac{0.86 h \cos \theta}{\sqrt{\lambda h}} \leq 0.45 h \cos \theta
$$

Comparing analytical methods to experimental data, Tucker [21] proposed Equation 7 for calculating the width of diagonal strut $(w)$ :

$w=0.25 L_{d}(\lambda h)^{-1.15}$

where $L_{d}$ is the length of diagonal, $h$ is the height of the panel and $\lambda$ is the same as defined in Equation 2. Tucker [21] also presented two groups of equations that predict the cracking strength of the panel $\left(P_{f c}\right)$ and the ultimate load capacity of the infilled frame $\left(P_{u l t}\right)$ for different types of masonry, depending on the compressive strength of the masonry infill $\left(f_{m}^{\prime}\right)$, of the width of diagonal $(w)$, of the slope between diagonal and horizontal $(\theta)$, and of the thickness of infill $(t)$. Equations 8 and 9 allow estimating $P_{f c}$ and $P_{u l t}$ for infills of masonry concrete blocks.

$P_{f c}=0.6 f^{\prime}{ }_{m} w t \cos \theta$

$$
P_{u l t}=1.05 f^{\prime}{ }_{m} w t \cos \theta
$$


It is important to mention that the compressed diagonal strut model is a simplified method and limited to linear analysis and is not effective after the cracking limit of the infill wall. This is because the system stiffness gradually decreases with the increase in lateral strength and the appearance of cracks in the panel, which makes the compressed diagonal model less consistent with the actual behavior of the structure. Then, the model can be used to check the service limit state of the structure and is not suitable for verifications of the ultimate limit state [22]. After defining the geometric properties of the diagonal strut, it is possible to determine internal forces in each structural member and the frame lateral displacements with a 2D frame model stiffened by the inclusion of the pinned diagonal strut.

The diagonal strut formulations for the consideration of masonry infill were developed to evaluate the masonry behavior when considered in the lateral stiffening of general framed structures taking into account the physical and mechanical properties of the masonry and of the frame materials. There are no limitations on the use of these expressions for different materials and different connection conditions of structural elements.

\subsection{Codes which consider masonry infill contribution}

\subsubsection{Determination of the width of diagonal strut}

\subsubsection{According to ABNT NBR 16868:2020 [23]}

For designing purposes, the Brazilian code admits that geometric properties of compressed diagonal strut depend on the length of contact between panel and column $\left(\alpha_{H}\right)$ and between panel and beam $\left(\alpha_{L}\right)$, expressed by Equations 10 and 11:

$\alpha_{H}=\frac{\pi}{2} \cdot \sqrt[4]{\frac{4 E_{p} I_{p} H}{E_{a} t_{a p} \sin (2 \theta)}}$

$\alpha_{L}=\pi \cdot \sqrt[4]{\frac{4 E_{p} I_{v} L}{E_{a} t_{a p} \sin (2 \theta)}}$

where:

$E_{a}$ and $E_{p}$ are the modulus of elasticity of masonry and frame material, respectively;

$I_{p}$ and $I_{v}$ are the moments of inertia of the cross section of columns and beam of the frame, respectively;

$H$ and $L$ are the height and length of infill panel, respectively;

$t_{a p}$ is equal to twice the sum of the thickness of longitudinal walls of the block for the case of hollow block not fully grouted; or it is the wall thickness for a solid brick or hollow block fully grouted;

$\theta$ is the angle of inclination of the diagonal strut, that is, equal to $\tan ^{-1}(\mathrm{~h} / \mathrm{l})$.

It is observed that this procedure is based on the apparent thickness of infill panel instead of the total thickness ( $\left.\mathrm{t}_{\mathrm{ap}}\right)$, in the case of hollow blocks. Such consideration comes from the fact that, in practice, masonry walls are neither commonly built with solid blocks nor do have hollow blocks grouted in their entirety. In the Brazilian design, masonry properties (including $\mathrm{E}_{\mathrm{a}}$, prism strength, wall geometry) refers to the masonry gross area. The use of the total thickness of the block in this situation would not be consistent with the formulations assessed in the former section. Considering the $t_{a p}$, which basically multiply by two the effective masonry thickness, makes the formulation consistent to the gross area properties, since regular hollow blocks have the gross area approximately equal to twice the net area.

From this, the width of equivalent diagonal $(w)$ can be determined by Equation 12.

$w=\sqrt{\alpha_{H}^{2}+\alpha_{L}^{2}}$

However, to consider an idealized and safe stress distribution, the effective width of compressed diagonal ( $\left.w_{\text {eff }}\right)$ is taken as $w / 2$ and must not exceed a quarter of the diagonal length.

An important recommendation is that the effective stiffness of compressed diagonal, used for displacement calculations, must be reduced by $50 \%$ of its nominal value, in order to consider the panel in cracked conditions. 


\subsubsection{According to TMS 402-16 [24]}

The American code TMS 402-16 [24] uses Equation 13 to calculate the width of diagonal strut:

$w_{\text {inf }}=\frac{0.3}{\lambda_{\text {strut }} \cos \theta_{\text {strut }}}$

where:

$$
\lambda_{\text {strut }}=\sqrt[4]{\frac{E_{m} t_{\text {netinf }} \sin 2 \theta_{\text {strut }}}{4 E_{b c} I_{b c} h_{\text {inf }}}}
$$

$E_{m}$ and $E_{b c}$ are the modulus of elasticity of masonry and frame material respectively;

$I_{b c}$ is the moment of inertia of the cross section of columns and beam of the frame;

$h_{\text {inf }}$ is the height of infill panel;

$t_{n e t, i n f}$ is the effective thickness of panel;

$\theta_{\text {strut }}$ is the angle between diagonal and horizontal axis.

In addition, the American code also recommends that a 50\% reduction shall be applied to the load capacity and stiffness of the diagonal strut.

\subsubsection{According to NZS 4230:2004 [25]}

The New Zealand code NZS 4230:2004 [25] recommends that the diagonal strut width shall be taken as a quarter of the diagonal length.

The thickness of the diagonal strut is taken as the effective thickness of masonry panel, the same way it was considered in the analysis of the American codes.

\subsubsection{Determination of masonry ultimate load capacity}

Three modes of failure are foreseen for the masonry infill, namely: bed-joint sliding, diagonal tension failure, and diagonal compression failure. In this section, equation to predict the ultimate load capacity for these three failure modes are presented, following the recommendations of the Brazilian code ABNT NBR 16868:2020 [23] and the American guidelines from FEMA 306 [26]

The horizontal force applied to the structure at the height of upper beam axis is considered as $F_{H}$. The compression axial force acting on the diagonal strut is $N$ and its horizontal $(V)$ and vertical $(P)$ components are given by Equations 15 and 16 , respectively.

$V=N \cos \theta$

$P=N \sin \theta$

\subsubsection{According to ABNT NBR 16868:2020 [23]}

The compressive strength of the diagonal strut is calculated in the same way as structural masonry walls, except that it must be multiplied by a factor which adjust the compressive strength normal to the bed joint to the resistance in the diagonal direction. In the absence of this information, the code states that this factor should be taken equal to 0.5 . Thus, the compressive strength can be calculated by Equation 17, where $R$ is a factor that considers the effects of slenderness; and $f_{m}$ is the average compressive strength of masonry walls, taken as $70 \%$ of the average compressive strength of the prisms $\left(f_{\mathrm{pm}}\right)$ obtained experimentally, as reported in De Grandi [14] It should be note that the code specifies characteristics values, but average values are considered here for assessing the test results.

$$
f_{k, \text { strut }}=0.5 f_{m} R
$$


where:

$$
f_{m}=0,7 f_{p m}
$$

$$
R=1-\left(\frac{\lambda}{40}\right)^{3}
$$

$\lambda=\frac{h_{e f}}{t_{e f}}$

The effective height $\left(h_{e f}\right)$ of the compressed diagonal must be considered equal to the length of the diagonal minus $w / 2$.

For design purposes, the diagonal strut cross section area is taken as the product between the effective width ( $\left.w_{\text {eff }}\right)$ and the infill thickness $(t)$. In this case, the maximum load that can be applied on the panel is given by limiting the compressive stress $\left(\sigma_{d}\right)$ to less than or equal to the masonry compressive strength $\left(f_{d}\right)$.

For the verification of the bed-joint sliding, the masonry shear strength was adopted equal to the average value determined experimentally from wall shear tests $\left(f_{v m}=0.2 \mathrm{MPa}=0.02 \mathrm{kN} / \mathrm{cm}^{2}\right)$, see De Grandi [14] Thus, shear stress must be less than or equal to this resistance value, that is, $\tau \leq f_{v m}$. In the case of bed-joint sliding, shear force occurs through the horizontal component of the diagonal compression V. Then, Equation 21 is used for this verification.

$$
\tau=\frac{V}{A_{c i s}} \leq f_{v m}
$$

The area resisting to the shear load on the panel $\left(A_{c i s}\right)$ is given by the length of the panel $(l)$ multiplied by its total thickness $(t)$.

In the case of the shear strength by diagonal tension, even that it is not provided by the Brazilian code for masonry infills, this check is implicit in item 11.4.3 of ABNT NBR 16868: 2020 [23], which deals with the verification of shear in elements of masonry. The shear strength is limited by Equation 22:

$$
f_{v k}=0.4 \gamma_{g} \sqrt{f_{p k}}
$$

where:

$f_{p k}$ is the characteristic compressive strength of the prism. In this case, the average compressive strength obtained experimentally $\left(f_{p m}\right)$ was used; $\gamma_{g}$ is the coefficient which considers the possibility of the wall being totally grouted or made of solid blocks. It must be equal to 1.0 for these cases, or equal to the ratio between the effective area of mortar and the gross area of the block, not exceeding 0.5 .

In the same way as other verifications, the critical force of failure by diagonal tension is obtained from the premise that stresses $(\tau)$ must be smaller than the strength $\left(f_{v}\right)$.

\subsubsection{According to FEMA 306 [26]}

For evaluation of initial shear strength due to bed-joint slipping, the American code uses the Mohr-Coulomb criterion. Hence, the critical horizontal force for this failure mode is given by Equation 23.

$$
V_{\text {slide }}=\left(\tau_{0}+\sigma_{y} \tan \varnothing\right) L_{\text {inf }} t_{\text {inf }}
$$

where:

$L_{i n f}$ and $t_{i n f}$ are the length and thickness of the infill panel, respectively;

$\phi$ is the angle of friction of the masonry along the bed joint; 
$\sigma_{y}$ is the pre-existing vertical compression stress on the panel; and

$\tau_{0}$ is the mortar cohesion, which can be estimated by Equation 24 in the absence of data:

$\tau_{0}=\frac{f^{\prime}{ }^{\prime} e^{90}}{20}$

being $f_{m e 90}^{\prime}=$ compressive strength of masonry in the horizontal direction, taken as $50 \%$ of the average compressive strength of prisms $\left(f_{p m}\right)$.

According to Federal Emergency Management Agency [26], the tangent of masonry friction angle (tan $\phi)$ is taken as the friction coefficient $\mu$, which value was considered as 0.5 , following recommendations from ABNT NBR 159611:2011 [27].

Regarding the diagonal compression failure mode, FEMA 306 [26] establishes the Equation 25 for determining the shear force resisted by the panel:

$V_{c}=a t_{\text {inf }} f_{\text {mego }}^{\prime} \cos \theta$

where $t_{i n f}, f_{m e 90}^{\prime}$ and $\theta$ are the same as previously defined; and $a$ is the width of the diagonal strut, calculated according to Equation 26:

$a=0.175\left(\lambda h_{c o l}\right)^{-0.4} r_{\text {inf }}$

in which:

$\lambda$ is the same as defined in Equation 2;

$h_{c o l}$ is the column height taken from axis to axis of beams; and

$r_{\text {inf }}$ is the diagonal length.

In case of failure by diagonal tension, the resistant force of the panel is given [26] by Equation 27:

$V_{c r}=\frac{2 \sqrt{2} t_{i n f} L_{i n f} \sigma_{c r}}{\left(\frac{L_{i n f}}{h_{i n f}}+\frac{h_{i n f}}{L_{i n f}}\right)}$

where

$h_{\text {inf }}$ is the height of infill;

$L_{\text {inf }}$ and $t_{\text {inf }}$ are the same as already defined; and

$\sigma_{c r}$ is the masonry cracking capacity, estimated by Equation 28:

$\sigma_{c r}=\frac{f^{\prime} m e 90}{20}$

being $f^{\prime}{ }_{m e 90}$ the same as previously defined.

\section{MATERIALS AND METHODOLOGY}

The study consisted of a numerical analysis of a steel frame infilled with a concrete masonry wall, subjected to horizontal loads, by using the equivalent diagonal strut method. The experimental data is taken from De Grandi [14]. Masonry infill wall was considered as a compressed strut connected to the frame by hinges. Furthermore, failure force of the masonry wall was estimated by prescriptions from technical codes.

To determine the width of diagonal strut, the procedures of American (TMS 402-16 [24]) and New Zealand (NZS 4230:2004 [25]) codes were compared, besides the Brazilian code ABNT NBR 16868:2020 [23]. Once the geometric 
properties of the diagonal were defined, a linear analysis of the steel frame was performed using the Ftool software to obtain the maximum lateral displacements at the top of the infilled frame. The diagonal strut was added to the structure with the geometric properties defined by the theoretical models and elastic properties of masonry. Figure 3 shows the structure modeling scheme, in which bottoms of the columns were simulated as perfectly rigid supports and beamcolumn connections were considered pinned. The displacements were analyzed until the lowest cracking load obtained in the experimental tests is reached, equals to $72 \mathrm{kN}$.

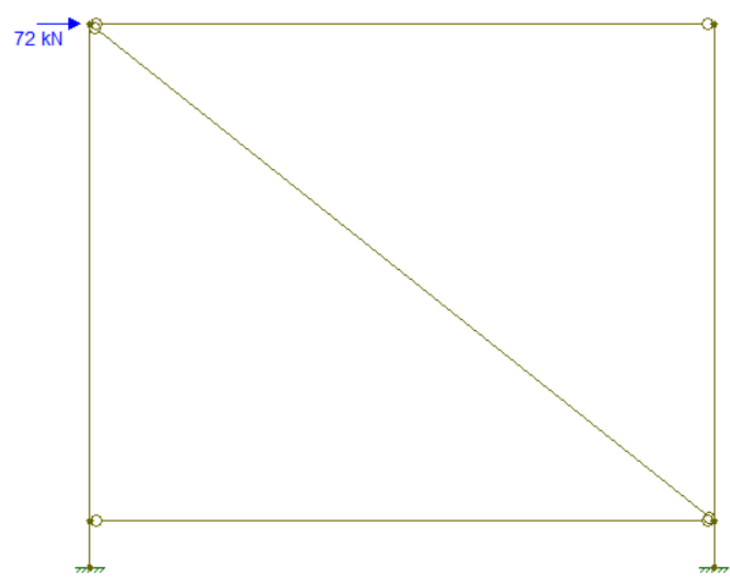

Figure 3. Structural model for linear analysis considering the equivalent diagonal strut. Source: The author

Regarding the verification of forces that leads the infill panel to failure, the following codes were evaluated: ABNT NBR 16868:2020 [23] and FEMA 306 [26].

For analysis purposes, the same materials tested by De Grandi [14] were used as parameters. De Grandi [14] dealt with the experimental evaluation of a steel frame infilled with concrete masonry, which properties are presented in section 3.1, under cyclic loads. The theoretical results obtained from the guidelines mentioned above were compared with the experimental results of De Grandi [14], discussing relevance and limitations of these methods.

\subsection{Material properties and description of experimental tests}

The frame structure from De Grandi [14] was constituted of ASTM A36 steel welded members, with a height/length ratio equal to 0.83 , being a full-scale specimen. Beams and columns were made by the same steel profile, with cross section indicated in Figure 4. Columns had a total length of $268 \mathrm{~cm}$, while beams had a length of $300 \mathrm{~cm}$ (from axis to axis of column). Column bottoms were fixed in the laboratory reaction slab and beam-column connections were made with bolted angles.
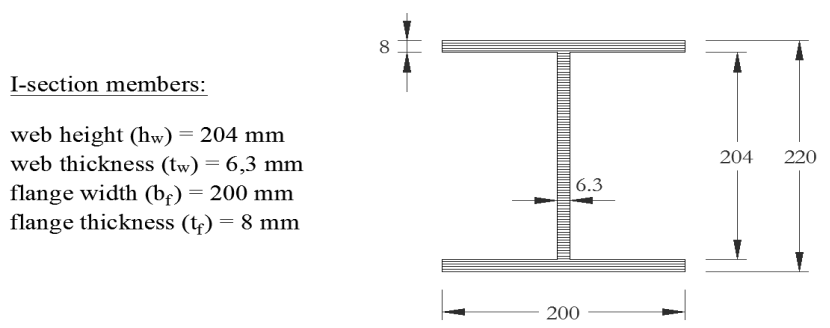

Figure 4. Steel cross section of columns and beams used by De Grandi [14]. Source: De Grandi [14]

The infill walls were built with hollow concrete blocks with compressive strength of $6 \mathrm{MPa}$ and dimensions of 14 x 19 x $39 \mathrm{~cm}$. Industrialized mortar with $6 \mathrm{MPa}$ compressive strength was used to completely fill vertical and horizontal joints. The frame-panel interfaces were filled by industrialized mortar with an expansive admixture. 
Frame tests were performed by the application of horizontal cyclic loading applied at the level of upper beam axis, through a hydraulic actuator model MTS DuraGlide 244.31 from MTS company. Figure 5 illustrates the experimental setup, showing the structural arrangement and force application system.

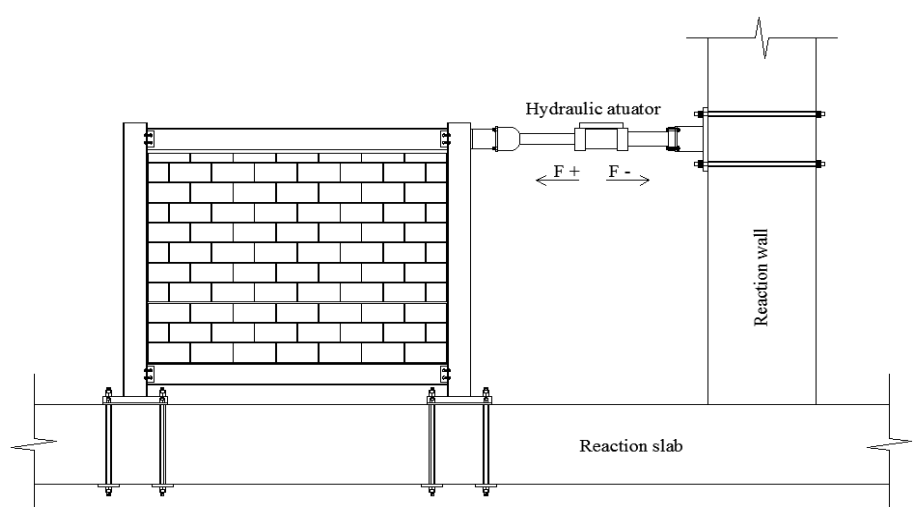

Figure 5. Experimental setup by De Grandi [14]. Source: De Grandi [14]

The summary of material properties used in the experimental program is shown in Table 1. Three infilled frames tests were carried out, namely PP-1-0.5/2.0, PP-2-CE-0.5/2.0 and PP-3-CE-0.5/2.0, under the same test conditions, and the experimental results were compared with theoretical analysis in this work.

Table 1. Material properties of experimental tests from De Grandi [14]

\begin{tabular}{|c|c|c|}
\hline Frame & Symbol & Value \\
\hline Steel modulus of elasticity & $E f$ & $200 \mathrm{GPa}$ \\
\hline Moment of inertia (columns and beams) & $I c$ and $I b$ & $4043 \mathrm{~cm}^{4}$ \\
\hline Masonry & Symbol & Value \\
\hline Height of panel & $h$ & $213 \mathrm{~cm}$ \\
\hline Length of panel & $l$ & $278 \mathrm{~cm}$ \\
\hline Nominal thickness of panel & $t$ & $14 \mathrm{~cm}$ \\
\hline Effective thickness of panel & te & $5.6 \mathrm{~cm}$ \\
\hline Masonry modulus of elasticity & $E m$ & $4 \mathrm{GPa}$ \\
\hline Compressive strength of blocks & $f b k$ & $6.13 \mathrm{MPa}$ \\
\hline Average compressive strength of prisms & fpm & $5.55 \mathrm{MPa}$ \\
\hline Average shear strength of masonry & fvm & $0.2 \mathrm{MPa}$ \\
\hline
\end{tabular}

\section{RESULTS AND DISCUSSIONS}

\subsection{Lateral displacements of the infilled frame}

\subsubsection{Calculation of the equivalent diagonal strut width $(w)$}

The specifications of three normative codes were taken as reference for determining the width of equivalent diagonal strut of the masonry infilled frame studied in this work. There are the Brazilian code ABNT NBR 16868:2020 [23], the American code TMS 402-16 [24] and the New Zealand code NZS 4230:2004 [25].

As described in section 2, ABNT NBR 16868:2020 [23] establishes a procedure for calculating the diagonal width of the equivalent strut according to Equations 10,11 and 12. Therefore,

$\alpha_{H}=\frac{\pi}{2} \sqrt[4]{\frac{4 E_{p} I_{p} H}{E_{a} t_{a p} \sin (2 \theta)}}=\frac{\pi}{2} \sqrt[4]{\frac{4 \times 200 \times 4043 \times 213}{4.00 \times 11.2 \times \sin \left(2 \times 37.46^{\circ}\right)}}=99.23 \mathrm{~cm}$ 
$\alpha_{L}=\pi \sqrt[4]{\frac{4 E_{p} I_{v} L}{E_{a} t_{a p} \sin (2 \theta)}}=\pi \sqrt[4]{\frac{4 \times 200 \times 4043 \times 278}{4.00 \times 11.2 \times \sin \left(2 \times 37.46^{\circ}\right)}}=212.13 \mathrm{~cm}$

$w=\sqrt{{\alpha_{H}{ }^{2}+\alpha_{L}{ }^{2}}^{2}}=\sqrt{99.23^{2}+212.13^{2}}=234.19 \mathrm{~cm}$

However, the effective width of compressed diagonal $\left(w_{\text {eff }}\right)$ is taken as $w / 2$ and must not exceed a quarter of the diagonal length. So,

$w_{\text {eff }}=\frac{w}{2}=\frac{234.19}{2}=117.09 \mathrm{~cm}$

$\frac{L_{d}}{4}=\frac{350}{4}=87.5 \mathrm{~cm}$

Therefore, in this case, the effective width of compressed diagonal must be taken as a quarter of its length $L_{d}$. That is, $w_{\text {eff }}=87.5 \mathrm{~cm}$.

According to TMS 402-16 [24], the width of the diagonal strut is determined following Equations 13 and 14, presented in section 3.2.2. Using the known properties of the frame and of the masonry yields to:

$\lambda_{\text {strut }}=\sqrt[4]{\frac{E_{m} t_{\text {netinf }} \sin \left(2 \theta_{\text {strut }}\right)}{4 E_{b c} I_{b c} h_{\text {inf }}}}=\sqrt[4]{\frac{4.00 \times 5.6 \times \sin \left(2 \times 37.46^{\circ}\right)}{4 \times 200 \times 4043 \times 213}}=0.0133 / \mathrm{cm}$

$w=\frac{0.3}{\lambda_{\text {strut }} \cos \theta_{\text {strut }}}=\frac{0.3}{0.0133 \times \cos 37.46^{\circ}}=28.4 \mathrm{~cm}$

The New Zealand code NZS 4230:2004 [25] recommends that the width of diagonal strut be taken as a quarter of the length of the diagonal. Therefore,

$w=\frac{L_{d}}{4}=\frac{350}{4}=87.5 \mathrm{~cm}$

\subsubsection{Obtention of lateral displacements}

Figure 6 shows a comparison among displacements obtained experimentally and analytically from the studied models.

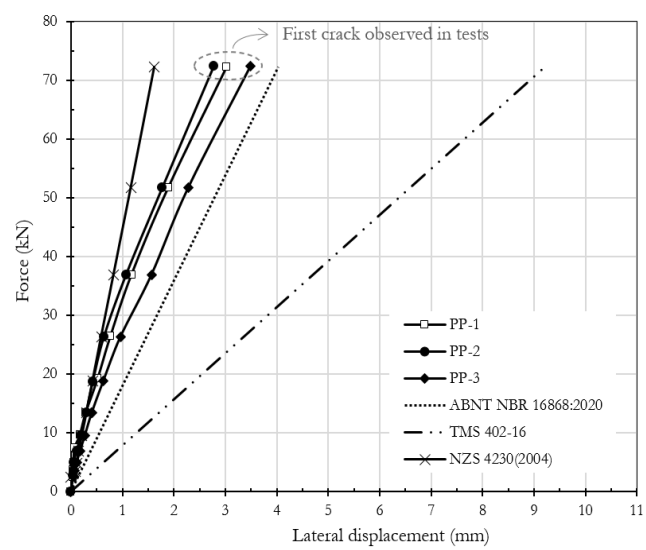

Figure 6. Load-displacement diagrams obtained from technical codes in comparison to experimental results. Source: The author 
It is possible to conclude that the American code TMS 402-16 [24] presents a more conservative method for considering masonry infill walls as bracing element, since lateral stiffness provided by the diagonal strut is much smaller than the values found experimentally and by other codes. Comprising the same levels of applied horizontal forces, the lateral displacements obtained by the method of TMS 402-16 [24] are much greater.

Specifications from the Brazilian code ABNT NBR 16868:2020 [23] showed stiffness values close to the experimental results. The observed difference can be attributed to uncertainties related to the behavior of the structure when masonry panel works as part of the bracing system, leading to a reduction in stiffness for design purposes.

On the other hand, the New Zealand code NZS 4230:2004 [25] presented a load-displacement curve with displacement values lower than experimental results, indicating a greater stiffness provided by the diagonal strut estimated by this guideline. However, it is possible to observe that, for lower loads (up to $25 \mathrm{kN}$ ), the New Zealand code demonstrated a good correlation with experimental results, with a greater discrepancy for higher load levels. This can be explained by the fact that, unlikely the other two codes, NZS 4230:2004 [25] does not consider a factor for reducing the stiffness of diagonal strut due to masonry wall cracking, which can develop internal microcracking, even if not showing visible cracks to unaided eye.

Table 2 shows the values of lateral stiffness for the three test specimens and for the theoretical models of equivalent diagonal strut. The proportion obtained for the stiffness of the theoretical models in relation to the average of experimental tests is also presented. It is observed that the stiffness of $17.9 \mathrm{kN} / \mathrm{mm}$ obtained by the ABNT NBR 16868:2020 [23] indicated a 76\% relationship with the experimental values. In contrast, the NZS 4230:2004 [25] code exhibited a stiffness of $32.0 \mathrm{kN} / \mathrm{mm}$, a value $36 \%$ higher than the experimental average. Finally, as previously mentioned, the method recommended by TMS 402-16 [24] proved to be the most conservative, presenting a stiffness of only $7.9 \mathrm{kN} / \mathrm{mm}$, equivalent to over $30 \%$ of the average value obtained in experimental tests.

Table 2. Relative lateral stiffnesses for experimental tests and theoretical methods.

\begin{tabular}{|c|c|c|}
\hline Specimen / Theoretical model & Stiffness $(\mathrm{kN} / \mathrm{mm})$ & $\mathbf{K}_{\text {theor }} / \mathbf{K}_{\exp }$ \\
\hline PP-1-0.5/2.0 & 23.9 & - \\
\hline PP-2-CE-0.5/2.0 & 26.1 & - \\
\hline PP-3-CE- $0.5 / 2.0$ & 20.7 & - \\
\hline ABNT NBR 16868:2020 & 17.9 & 0.76 \\
\hline TMS $402-16$ & 7.9 & 0.33 \\
\hline NZS 4230:2004 & 32.0 & 1.36 \\
\hline
\end{tabular}

\subsection{Estimation of the infill failure load}

Table 3 presents a summary of the theoretical results for failure loads of the studied infill panel. The values presented herein refer to the critical horizontal force applied to the frame $\left(F_{H}\right)$ for each analyzed failure mode. For comparison purposes, it is indicated that masonry critical forces observed experimentally were $72 \mathrm{kN}, 101 \mathrm{kN}$ and $75 \mathrm{kN}$ for the three test specimens. Figure 7 shows the final cracking pattern at the masonry infill wall after the end of the test, for the PP-2-CE-0.5/2.0 specimen, being that this typical behavior mode was also observed on the other tests, indicating failure by diagonal tension.

Table 3. Masonry failure loads by technical codes.

\begin{tabular}{ccc}
\hline Technical code & Behavior mode & Failure load (kN) \\
\hline \multirow{2}{*}{ ABNT NBR 16868:2020 } & Diagonal compression & 209 \\
\cline { 2 - 3 } & Bed-joint sliding & 91 \\
\cline { 2 - 3 } & Diagonal tension & 214 \\
\hline \multirow{2}{*}{ FEMA 306 (1998) } & Diagonal compression & 131 \\
& Bed-joint sliding & 106 \\
\hline
\end{tabular}




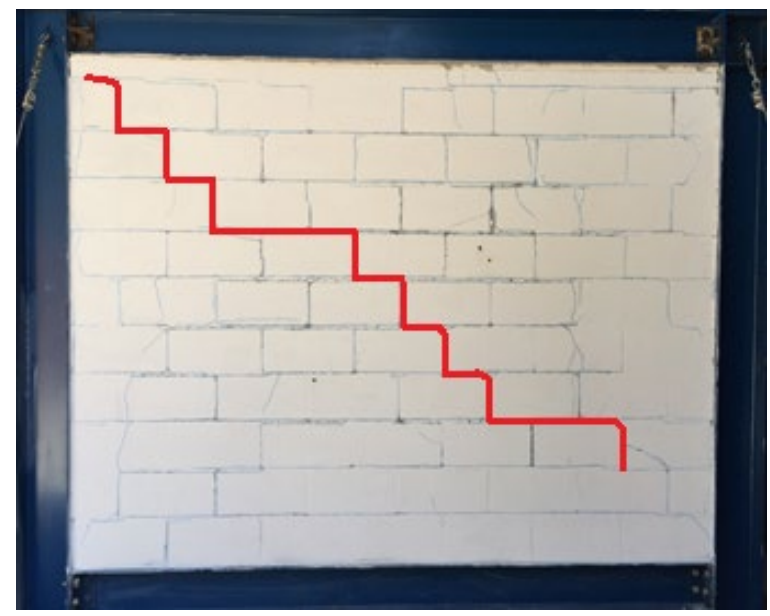

Figure 7. Typical masonry cracking after failure - PP-2-CE-0.5/2.0 (Highlighted in red: first crack register). Source: De Grandi [14]

Regarding the results of theoretical analysis, it is observed that the values of failure load obtained by ABNT NBR 16868: 2020 [23] indicate that the critical failure mode is the bed-joint slipping, which presented an estimated critical force of $91 \mathrm{kN}$. The calculated diagonal tension failure load was equal to $214 \mathrm{kN}$, considerably higher than the experimental values.

On the other hand, FEMA 306 [26] presents diagonal tension as a critical failure mode, which was observed during the experimental tests. The failure load was $89 \mathrm{kN}$, like the critical force value obtained by the Brazilian code, although the failure modes indicated by these two guidelines were different. The infill diagonal compression was not a critical failure mode, presenting a failure force of $131 \mathrm{kN}$.

\section{CONCLUSIONS}

The contribution of masonry walls to the stiffening of framed structures is undeniable. However, despite numerous studies already carried out and findings regarding the effectiveness of infill panels, the consideration of these elements as part of the structural bracing system is still unusual.

After the analyses of a steel frame infilled with concrete masonry, the following conclusions can be stated:

- In terms of stiffness, the American code TMS 402-16 [24] proved to be the most conservative method, presenting the lowest lateral stiffness among all the assessed diagonal strut models. The Brazilian code (ABNT NBR 16868:2020 [23]) proved to be less conservative even though the calculated contribution of the masonry wall to the stiffening of the structure was smaller than the measured experimental tests average. The New Zealand code (NZS 4230:2004 [25]) reached stiffness values higher than the results of experimental tests for accentuated loads. This may be associated with the fact that this guideline does not predict a reduction factor in the stiffness of the diagonal strut to consider a stiffening decrease due to cracking of masonry;

- Concerning the ultimate load, those determined by the Brazilian code equations [23] indicated a joint sliding shear failure, while the results obtained by equations from FEMA 306 [26] indicate the critical diagonal tension failure, equivalent to the observations during experimental tests. Nevertheless, the value of critical force determined by FEMA 306 [26] was close to that obtained by ABNT NBR 16868:2020 [23].

It is important to highlight that the experimental results presented here were obtained by cyclic tests, in which the stiffness degradation may be greater than that observed in monotonic tests, due to the frequent variation on the direction of loading application. Even though, experimental results for stiffness proved to be higher than those calculated using code specifications.

In conclusion, the equivalent diagonal strut method, adopted by several authors and technical codes, proved to be a simple and useful tool for predicting the contribution of infill panels to structure stiffening. However, the model predicts the structure behavior in the initial cracking stages.

Finally, although the contribution of masonry panels in the lateral stiffness of the structure is demonstrated, the lack of a universally accepted theory for the analysis of such structural systems and the divergence observed between the methods available in the literature lead the consideration of infill panels as bracing elements to be treated with some 
caution in the new Brazil code specifications. It is recommended that studies about infilled frames be encouraged, to refine the simplified design methods.

\section{ACKNOWLEDGEMENTS}

This study was financed in part by the Coordenação de Aperfeiçoamento de Pessoal de Nível Superior - Brasil (CAPES) - Finance Code 001.

\section{REFERENCES}

[1] A. B. Mehrabi, P. B. Shing, M. P. Schuller, and J. L. Noland, "Experimental evaluation of masonry-infilled RC frames," J. Struct. Eng., vol. 122, no. 3, pp. 228-237, 1996.

[2] A. Kauffman and A. M. Memari, "Performance evaluation of different masonry infill walls with structural fuse elements based on inplane cyclic load testing," Buildings, vol. 4, pp. 605-634, 2014.

[3] S. M. M. Emami, M. Mohammadi, and P. B. Lourenço, "Equivalent diagonal strut method for masonry walls in pinned connection and multi-bay steel frames," J. Seismol. Earthq. Eng., vol. 19, no. 4, pp. 199-311, 2017.

[4] A. Mohebkhah, A. A. Tasnimi, and H. A. Moghadam, "Nonlinear analysis of masonry-infilled steel frames with openings using discrete element method," J. Construct. Steel Res., vol. 64, no. 12, pp. 1463-1472, Dec 2008.

[5] P. G. Asteris, D. J. Kakaletsis, C. Z. Chrysostomou, and E. E. Smyrou, "Failure Modes of In-filled Frames," Electron. J. Struct. Eng., vol. 11, no. 1, pp. 11-20, 2011.

[6] P. G. Asteris, C. Z. Chrysostomou, I. P. Giannopoulos, and E. Smyrou, "Masonry infilled reinforced concrete frames with openings," in III ECCOMAS Thematic Conf. Comput. Meth. Struct. Dyn. Earthq. Eng., Corfu, Grece, 2011, 15 p.

[7] P. G. Asteris, L. Cavaleri, F. Di Trapani, and A. K. Tsaris, "Numerical modelling of out-of-plane response of infilled frames: State of the art and future challenges for the equivalent strut macromodels," Eng. Struct., vol. 132, no. 1, pp. 110-122, 2017.

[8] L. Cavaleri and F. Di Trapani, "Cyclic response of masonry infilled RC frames: experimental results and simplified modeling," Soil. Dyn. Earthquake Eng., vol. 65, no. 1, pp. 224-242, 2014.

[9] P. B. Shing and A. B. Mehrabi, "Behaviour and analysis of masonry-infilled frames," Prog. Struct. Eng. Mater., vol. 4, pp. 320-331, 2002.

[10] N. M. Noh, L. Liberatore, F. Mollaioli, and S. Tesfamariam, "Modelling of masonry infilled RC frames subjected to cyclic loads: state of the art review and modelling with OpenSees," Eng. Struct., vol. 150, no. 1, pp. 599-621, 2017.

[11] D. Markulak, I. Radic, and V. Sigmund, "Cyclic testing of single bay steel frames with various types of masonry infill," Eng. Struct., vol. 51, no. 1, pp. 267-277, Jun 2013.

[12] R. C. S. S. Alvarenga "Análise teórico-experimental de estruturas compostas de pórticos de aço preenchidos com alvenaria de concreto celular autoclavado,” Ph.D. dissertation, Esc. Eng. São Carlos, Univ. São Paulo, São Carlos, 2002.

[13] A. Fiore, A. Netti, and P. Monaco, "The influence of masonry infill on the seismic behavior of RC frame buildings," Eng. Struct., vol. 44, no. 1, pp. 133-145, 2012.

[14] A. B. C. De Grandi, “Avaliação experimental por meio de ensaios cíclicos de pórtico de aço preenchido com alvenaria participante,” M.S. thesis, Univ. Fed. Viçosa, Viçosa, 2018.

[15] S. V. Polyakov, On the Interaction Between Masonry Filler Walls and Enclosing Frame When Loaded in the Plane of the Wall. San Francisco, EUA: Earthq. Eng. Res. Inst., 1960, pp. 36-42.

[16] M. Holmes, "Steel frames with brickwork and concrete infilling," Proc.- Inst. Civ. Eng., vol. 19, no. 4, pp. 473-478, 1961.

[17] B. Stafford-Smith and C. Carter, "A method of analysis for infilled frames," Proc.- Inst. Civ. Eng., vol. 44, no. 1, pp. 31-48, 1969.

[18] R. J. Mainstone, "On the stiffnesses and strengths of infilled frames," Proc.- Inst. Civ. Eng., vol. 49, no. 4, pp. 57-90, 1971.

[19] R. H. Wood, "Plasticity, composite action and collapse design of unreinforced shear wall panels in frames," Proc.- Inst. Civ. Eng., vol. 65 , no. 2 , pp. $381-411,1978$.

[20] T. C. Liauw and K. H. Kwan, "Plastic theory of non-integral infilled frames," Proc.- Inst. Civ. Eng., vol. 75, no. 2, pp. 379-396, 1983.

[21] C. J. Tucker, "Predicting the in-plane capacity of masonry infilled frames," Ph.D. dissertation, Tennessee Technol. Univ., Cookeville, TN, EUA, 2007.

[22] G. A. Parsekian, A. A. Hamid, and R. G. Drysdale, Comportamento e Dimensionamento de Alvenaria Estrutural, 2. ed. São Carlos: EdUFSCar, 2014.

[23] Associação Brasileira de Normas Técnicas, Alvenaria Estrutural - Parte 1: Projeto, NBR 16868:2020, 2020.

[24] The Masonry Society, Building Code Requirements for Masonry Structures, Masonry Standards Joint Committee, TMS 402-16, 2016. 
[25] New Zealand Standard, Design of Reinforced Concrete Masonry Structures, NZS 4230:2004, 2004.

[26] Federal Emergency Management Agency, Evaluation of Earthquake Damaged Concrete and Masonry Wall Buildings - Basic Procedures Manual, FEMA 306, 1998.

[27] Associação Brasileira de Normas Técnicas, Alvenaria Estrutural - Blocos de Concreto - Parte 1: Projeto, NBR 15961-1:2011, 2011.

[28] J. L. Dawe and C. K. Seah, "Behaviour of masonry infilled steel frames," Can. J. Civ. Eng., vol. 16, pp. 865-876, 1989.

[29] G. M. S. Alva, J. Kaminski Jr, G. Mohamad, and L. R. Silva, "Serviceability limit state related to excessive lateral deformations to account for infill walls in the structural model," Rev. IBRACON Estrut. Mater., vol. 8, no. 3, pp. 390-426, Jun 2015.

Author contributions: ABCDG: conceptualization, methodology, data curation, writing; RMS: methodology, formal analysis, supervision; RCSSA: supervision; JCLR: supervision, formal analysis; GAP: supervision, formal analysis; WAM: writing, formal analysis.

Editors: Fernando Fonseca, José Luiz Antunes de Oliveira e Sousa. 